\title{
Biological treatment of dairy wastewater by a sequencing batch flexible fibre biofilm reactor
}

\author{
M. E. Abdulgader ${ }^{1}$, Q. J. Yu ${ }^{1}$, P. Williams ${ }^{1} \&$ A. A. L. Zinatizadeh ${ }^{2}$ \\ ${ }^{1}$ Griffith School of Engineering, Griffith University, Australia \\ ${ }^{2}$ Material and Energy Research Centre, Iran
}

\begin{abstract}
Biological treatment of dairy wastewater was investigated using a laboratoryscale aerobic sequencing batch flexible fibre biofilm reactor (SBFFBR). The SBFFBR system was modified from a typical sequencing batch reactor (SBR) system by using eight simple flexible fibre bundles with a very high specific surface area, which served as a support for bacteria. The 8 litre Perspex flexible fibre reactor was developed for efficient and cost effective treatment of milk industry effluent. A fine bubble air diffuser supplied oxygen in the reactor. Raw dairy wastewater was fed to the reactor under different dilutions. The reactor was operated under different influent COD concentrations (610, 2041 and $4382 \mathrm{mg} / \mathrm{l})$ and constant hydraulic retention times (HRT) of 1.6 days. The results have shown successful applicability of the SBFFBR system, indicating high COD removal efficiencies between $89.7 \%$ and $97 \%$ at average organic loading rates of $0.42 \mathrm{~kg} \mathrm{COD} / \mathrm{m}^{3} . \mathrm{d}$ and $2.74 \mathrm{~kg} \mathrm{COD} / \mathrm{m}^{3} . \mathrm{d}$, respectively. Easy operation, low cost and minimal sludge production were some of advantageous of the process.
\end{abstract}

Keywords: wastewater treatment, biofilm reactor, flexible fibre packing, milk industry wastewater, sequencing batch reactor.

\section{Introduction}

The high cost of wastewater treatment for food industry wastes and increasingly stringent effluent regulations have increased interest in alternative treatment methods. The selection of a biological treatment process is based on the quality of effluent needed, type of wastewater, and costs of operation [1, 2]. The wastewater from food processing industries, such as milk processing, produce considerable quantities of wastewaters, characterised by high concentrations of 
COD, BOD, and TKN of up to $11,000 \mathrm{mg} / \mathrm{l}, 5900 \mathrm{mg} / \mathrm{l}$, and $720 \mathrm{mg} / \mathrm{l}$, respectively [2]. Consequently, they are commonly treated biologically $[4,5]$. Aerobic methods are considered to be the most cost effective $[1,3]$.

These processes are classified as either attached growth (biofilm) processes or suspended growth processes. Traditional continuous flow systems, such as the conventional activated sludge process, aerated lagoon, and oxidation pond, have been extensively utilised for various types of industrial wastewater [4-6]. However, these processes have difficulties in meeting effluent standards, and have high operation costs and sludge production [1, 5-7]. An alternative approach, the sequencing batch reactor (SBR) process, has exhibited an effective performance of organic carbon, nitrogen and phosphors removal within a single reactor for domestic and industrial wastewaters [1, 2, 8]. Furthermore, the flexible operation of the SBR process allows mimicking of many processes in conventional continuous-flow reactors and can yield superior performance [9]. The SBR process has overcome many obstacles and also differs from other suspended growth processes. The clearest difference is the reactor volume variation with the time, whereas it remains constant in the traditional continuous flow system [10]. Some studies $[2,11]$ reported an acceptable performance of the SBR process in treating dairy industrial wastewater with varied concentrations of COD and TSS. However, the SBR process still has some drawbacks, such as the high excess sludge produced under high organic loading, high sludge volume index, and lower removal efficiency due to increase of bio-sludge $[1,2]$.

The applications of aerobic biofilm processes in food processing wastewater treatment have been developed to avoid the drawbacks in suspended cell processes $[1,2,6,12,13]$. In the attached growth process, microorganisms are attached on an inert support media. The reactor biomass concentration is high due to a longer sludge age. Hence, the biofilm process can be much more resistant to shock organic loads $[6,9]$. Consequently, the treatment efficiency can be also improved. Furthermore, bulking problems for many of the attached growth systems limit their application.

A two-stage continuous flexible fibre biofilm reactor has been developed for the treatment of industrial wastewater and the treatability of food processing wastewater was investigated at $7.7 \mathrm{~kg} \mathrm{COD} / \mathrm{m}^{3} . \mathrm{d}$ and $8 \mathrm{~h} \mathrm{HRT}$. Overall, $96 \%$ COD removal efficiency has been achieved [6]. However, a through literature search showed that the performances of sequencing batch flexible fibre biofilm bioreactors (SBFFBR) has not been investigated with dairy industrial wastewater. This study aims to determine the treatability of dairy industrial wastewater by sequencing batch flexible fibre biofilm reactor (SBFFBR) and to evaluate the effect of organic loading rate on the reactor performance.

\section{Materials and methods}

\subsection{Experimental setup}

A laboratory scale SBFFBR Perspex system was used. A schematic of the experimental setup is shown in fig 1 . The fabricated SBFFBR had a cylindrical 
shape (120 mm diameter, $900 \mathrm{~mm}$ height) and working volume of $8 \mathrm{~L}$. Mixing and aeration were provided by ceramic porous diffusers at the bottom of the reactor. Air was provided via a blower. The DO concentration exceeded $4 \mathrm{mg}$ $\mathrm{O}_{2} / 1$. The SBFFBR was filled with eight bundles of simple flexible fibre made of rayon fibre. The fibre is $75 \mathrm{~mm}$ long when straightened, and $0.07 \mathrm{~mm}$ diameter, with a specific growth surface area of $2200 \mathrm{~m}^{2} / \mathrm{m}^{3}$ and avoid fraction of $>90 \%$. An $885 \mathrm{~mm}$ long rope was fixed vertically to a support frame and the bundles attached with an interval of about $80 \mathrm{~mm}$ and installed in the centre of the reactor [6].

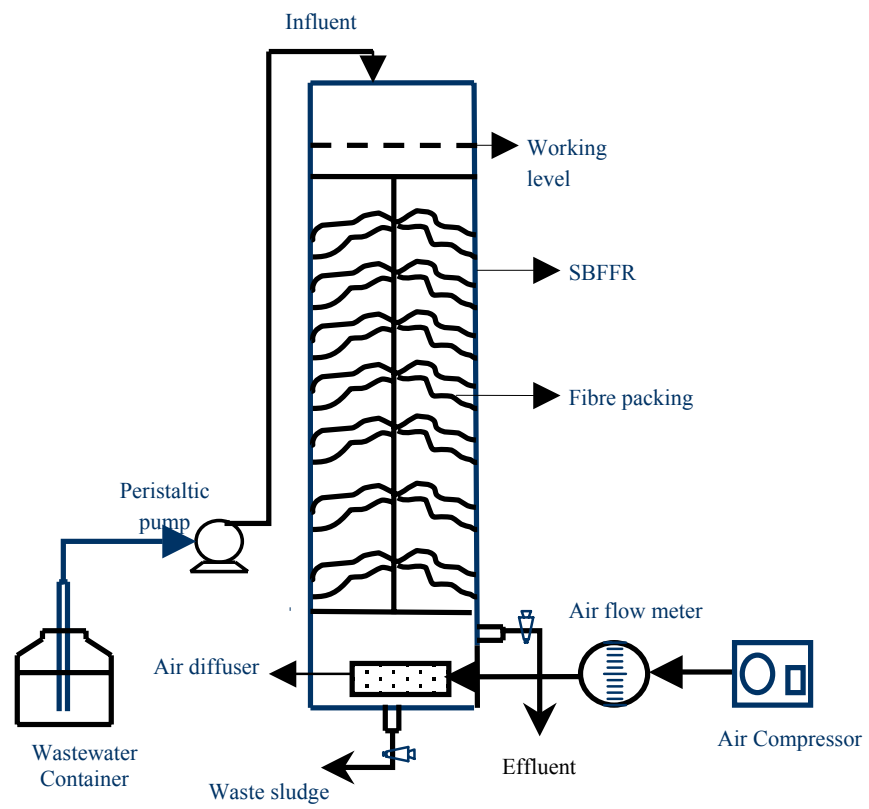

Figure 1: Schematic diagram of experimental setup.

Table 1: $\quad$ Characteristics of milk industrial wastewater.

\begin{tabular}{|c|c|}
\hline Parameters & Concentration, mg/l \\
\hline COD & $5000-14250$ \\
\hline BOD & $3000-8910$ \\
\hline pH & 11.70 \\
\hline Total Solids & $5790-6380$ \\
\hline Total Suspended Solid & $1420-3540$ \\
\hline Volatile Suspended Solid & $1350-3480$ \\
\hline Total Nitrogen (as N) & ND \\
\hline Total phosphate (as P) & 37 \\
\hline Oil and Grease & ND \\
\hline
\end{tabular}




\subsection{Wastewater and seed culture}

Milk industrial wastewater from National Food Ltd, Brisbane, Australia was used in the experiments. Approximately $100 \mathrm{~L}$ samples were regularly collected from the wastewater effluent stream every two months. The sample characteristics are shown in table 1 . The raw wastewater samples were diluted using tap water to have different COD concentrations in each experiment. Prior to feeding into the reactor, the $\mathrm{pH}$ was regularly checked and adjusted to neutral. The SBFFBR was inoculated with an activated sludge sample from Oxley creek wastewater treatment plant and Loganholme wastewater treatment plant. A volume of $1 \mathrm{~L}$ of mixed culture was fed to the SBFFBR as inoculum.

\subsection{Operation of the SBFFR system}

The operational sequence for different operations during each treatment cycle of SBFFBR consisted of 5 steps: a fresh raw dairy wastewater was pumped using a peristaltic pump (master flex model 7523-60 at $42 \mathrm{ml} / \mathrm{min}$ ) for a final volume of $8 \mathrm{~L}$ for a period of $2 \mathrm{~h}$ (Fill), the system was fully aerated and continued for another of $20 \mathrm{~h}$ of reaction (react). The air was shutdown and the reactor allowed settling down for approximately $1.5 \mathrm{~h}$ (settle). Then, for a period of $0.5 \mathrm{~h}$ (draw), the effluent was discharged and supernatant was removed from the effluent port based on the replacement volume shown in table 2 . The idle step was neglected in this experiment. Then, a fresh raw wastewater was filled into the reactor and the above sequence cycle repeated. This experiment was operated under different influent COD concentrations ranging between $(610-4382 \mathrm{mg} / \mathrm{l})$, and a constant hydraulic retention time HRT (1.6 day), for a period of 42 days until a pseudosteady state condition was achieved.

Table 2: $\quad$ Operation strategies of SBFFBR.

\begin{tabular}{|c|c|c|c|}
\hline \multirow[t]{2}{*}{ Parameters } & \multicolumn{3}{|c|}{ Wastewater Concentration } \\
\hline & $610 \mathrm{mg} \mathrm{COD} / 1$ & $2041 \mathrm{mg} \mathrm{COD} / 1$ & $4382 \mathrm{mg} \mathrm{COD} / 1$ \\
\hline HRT (d) & 1.6 & 1.6 & 1.6 \\
\hline Working volume, $\mathrm{L}$ & 8 & 8 & 8 \\
\hline Flow rate $1 / \mathrm{d}$ & 5 & 5 & 5 \\
\hline Replacement volume 1/d & 5 & 5 & 5 \\
\hline Operating cycle time/d & 1 & 1 & 1 \\
\hline Operating period (d) & 1 & 1 & 1 \\
\hline OLR $\mathrm{kg} \mathrm{COD} / \mathrm{m}^{3} \cdot \mathrm{d}$ & 0.38 & 1.27 & 2.74 \\
\hline AFR/WFR ratio ${ }^{*}$ & 1 & 1 & 2 \\
\hline
\end{tabular}

\subsection{Analytical procedures}

The influent and effluent were sampled each cycle and examined for parameters such as COD TSS, VSS, pH, DO, and Turbidity. The total (COD) was analysed by reactor digestion method using Hach Kit. TSS and VSS were measured based on the standard methods for the examination of water and wastewater [15] Dissolved oxygen (DO) and $\mathrm{pH}$ were monitored with meters each cycle. 
Turbidity was measured by turbidity meter model Hach $2100 \mathrm{~A}$. The experiment was carried out at room temperature $\left(22 \pm 2{ }^{\circ} \mathrm{C}\right)$.

\section{Results and discussion}

A sequencing batch flexible fibre biofilm reactor is one of the newly developed biofilm reactors now used in the treatment of milk processing wastewater effluent. The reactor retains a high biomass concentration, due to the packing media used with a high specific surface area for microorganisms' attachment. Therefore, the system has the ability to treat wastewaters that contain high quantity of organic matter. In addition, it can also resist high organic and hydraulic shock loading.

It is evident from the previous results presented that with increase in organic loading rate (OLRs), the COD removal rate of the system is reduced. To achieve stable reactor performance at low concentrations, the reactor required a few days to stabilize, typically less than 14 days, but it may require longer as the OLRs are increased, as the microorganisms need more time to adjust to the higher loads.

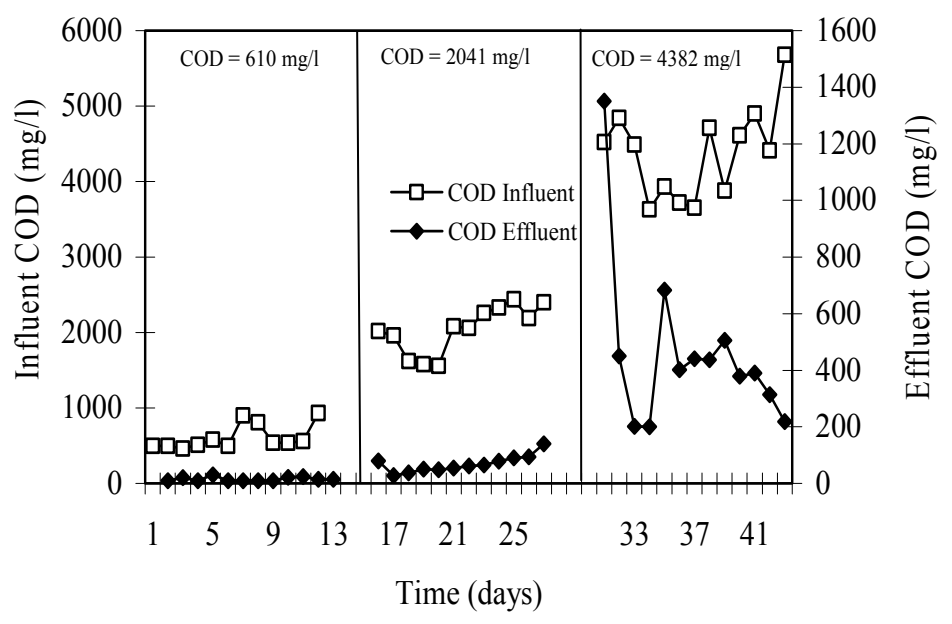

Figure 2: $\quad$ Variation of influent and effluent COD in SBFFBR.

The SBFFBR was operated with a $24 \mathrm{~h}$ cycle period to assess the performance of the reactor for treating milk industrial wastewater. The variation of COD concentrations in the influent and effluent with respect to operation time is depicted in fig. 2. The reactor was run at three different COD concentrations. Firstly, a set of experiment was carried out at low influent COD value of 610 $\mathrm{mg} / \mathrm{l}\left(0.38 \mathrm{~kg} \mathrm{COD} / \mathrm{m}^{3} . \mathrm{d}\right)$. At this stage, the reactor attained a very high performance with an average effluent COD concentration of $15.4 \mathrm{mg} / \mathrm{l}$. In the second trial, influent COD concentration of the reactor was increased to an average $2041 \mathrm{mg} \mathrm{COD} / 1\left(1.27 \mathrm{~kg} \mathrm{COD} / \mathrm{m}^{3}\right.$.d). An average of $69 \mathrm{mg} / 1 \mathrm{of}$ effluent COD was produced. Thirdly; the SBFFBR was operated at high influent COD 
concentration with an average of $4382 \mathrm{mg} / \mathrm{l}$ (OLR $2.74 \mathrm{~kg} \mathrm{COD} / \mathrm{m}^{3}$.d). An effluent with a COD concentration of $459.4 \mathrm{mg} / \mathrm{l}$ could be obtained. However, in the first case, the reactor approached $1350 \mathrm{mg} / \mathrm{l}$ of COD effluent. Such a low result is attributed to the sudden increase of influent COD. Generally, a variation in the influent COD concentration may be attributed to the degradation in the equalization tank. Similarly, the average of $750 \mathrm{mg} / \mathrm{l}$ of COD effluent $(89.3 \%$ removal efficiency) obtained by using SBR biofilm for treatment of milk industrial wastewater at 3 days HRT, showed an effluent concentration decrease with increased HRT (Sirianuntapilboon et al [2]). Hence, about $35 \mathrm{mg} / \mathrm{l}$ of effluent COD was produced obtained with $773 \mathrm{mg} / \mathrm{l}$ influent of synthetic wastewater treated by a sequencing batch biofilm reactor (SBBR) (Rodgers et al [16]). The SBFFR system achieved a higher COD effluent compared with previous studies, due to the increased amount of biofilm mass on the media.

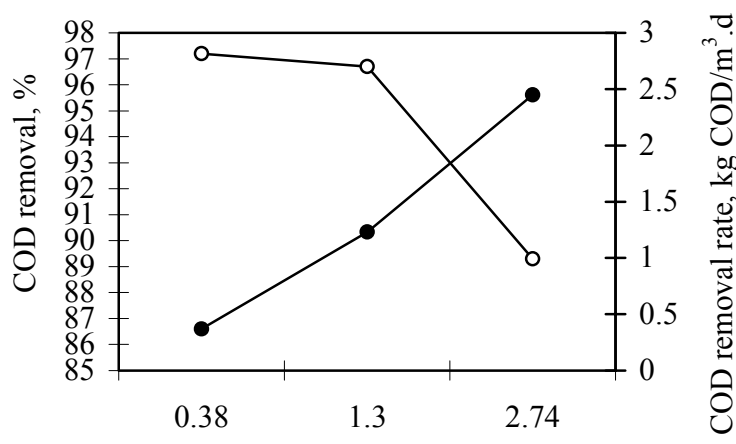

Organic loading rate, $\mathrm{kg} \mathrm{COD} / \mathrm{m}^{3} . \mathrm{d}$

$\multimap-\%$ COD removal $\longrightarrow$ COD removal rate

Figure 3: $\quad$ Reactor performance at HRT of 1.6 day.

In this research project, the reactor performance was evaluated by carrying out number of experiments at a fixed HRT (1.6 day) and COD (610-4280 mg/l) (corresponding to organic loading rates ranging between $0.38-2.74 \mathrm{~kg}$ $\mathrm{COD} / \mathrm{m}^{3}$.d). Fig. 3 presents variations of COD removal efficiency and COD removal rate as a function of the $\mathrm{COD}$ organic loading rates (OLRs). At low OLRs of 0.4 and $1.3 \mathrm{~kg} \mathrm{COD} / \mathrm{m}^{3} . \mathrm{d}$, high COD removal efficiencies of $97 \%$ and $96 \%$ were achieved, respectively. But, the efficiency decreased to around $89 \%$ at $2.74 \mathrm{~kg} \mathrm{COD} / \mathrm{m}^{3}$.d. Similarly, Yu et al [6] reported a COD removal efficiency of $90 \%$ at $1.04 \mathrm{~kg} \mathrm{COD} / \mathrm{m}^{3}$.d treating food processing wastewater in a comparable reactor. Sirianuntapiboon et al [2] also achieved almost similar performance $(89.3 \%)$ at OLR of $1.340 \mathrm{~g} \mathrm{BOD} / \mathrm{m}^{3} . \mathrm{d}$. However, a high COD (97.4\%) was obtained in a rotating biological contactor $\left(\mathrm{RBC}\right.$ at $18.44 \mathrm{~g} / \mathrm{m}^{2} . \mathrm{d}$, indicating relatively high removal rate in such a biofilm reactor Najafpour et al [13]. Despite the fact that SBFFR achieved around $89 \%$ of COD removal efficiency when OLRs increased to $2.74 \mathrm{~kg} \mathrm{COD} / \mathrm{m}^{3} . \mathrm{d}$, similarly Najafpour et al [13] demonstrated less removal efficiency $(85.4 \%)$ of COD when the OLRs increased to $36.89 \mathrm{~g} / \mathrm{m}^{2}$.d. 
In contrast, the rate of COD removal showed an increasing tendency from 0.37 to $2.45 \mathrm{~kg} \mathrm{COD} / \mathrm{m}^{3} . \mathrm{d}$ with increase in OLR, indicating high treatment capacity of the system. With an OLR of $2.75 \mathrm{~kg} \mathrm{COD} / \mathrm{m}^{3} . d$, specific substrate utilization rate was calculated to be $4.64 \mathrm{~g} \mathrm{COD}_{\mathrm{rem}} / \mathrm{g}$ VSS.d. Note that with increasing COD removal rate, oxygen uptake rate (OUR) was also increased (to the level below $1 \mathrm{mgO}_{2} / \mathrm{L}$ ), so that it compensated with increasing the air flow rate.

Fig. 4 illustrates the overall removal efficiency (\%) of the reactor as a function of time (days). Generally, it can be seen that SBFFR removed a high level of COD effectively for all different COD concentration studied. It attained a slightly superior average of $94.4 \%$ of COD removal efficiency. Basically, a high removal efficiency of COD can be achieved at low COD concentration (Metcaff and Eddy [1]). The COD removal efficiency of SBFFBR approached $97 \%$ when the reactor operated at influent COD concentrations of $610 \mathrm{mg} / \mathrm{l}$ and $2040 \mathrm{mg} / \mathrm{l}$, respectively. Fig. 4 shows that for COD concentrations of less than 1000 and $2041 \mathrm{mg} / \mathrm{l}$, the COD removal efficiency was very high (around 97\%) and was quite constant over the time interval up to 14 days. However, the removal efficiency dramatically decreased to $89.3 \%$ as the influent concentration of COD increased to $4382 \mathrm{mg} / \mathrm{l}$. The COD removal efficiency showed more variation, was generally lower, but towards the end of the 14 day period, the removal efficiency was comparable with that at the two lower COD concentrations. Findings reported by Bandpi and Bazari [11] for SBR system treating dairy wastewater achieved COD removal efficiency around 90\% with COD concentrations varying from $400-2500 \mathrm{mg} / \mathrm{l}$.

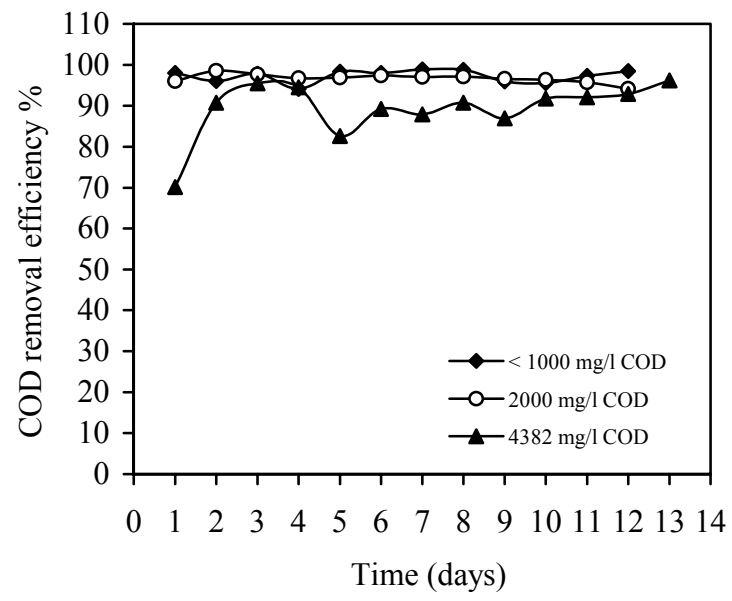

Figure 4: COD removal efficiencies of SBFFBR.

The quality of the effluent of SBFFBR system is summarized in table 3. It can be seen that a high quality effluent could be achieved when the reactor operated at low COD influent concentration $(610 \mathrm{mg} / 1$ and $2041 \mathrm{mg} / \mathrm{l})$. The amount of 
COD applied to the system has a significant effect on the reactor performance; the Do level in the treated effluent is decreased as by about $75 \%$ from $5.9-1.32$ $\mathrm{mg} \mathrm{O}_{2} / 1$ ) which is attributed to the increase of the activity of biomass mass as the substrate concentration increased. However, the turbidity of the effluent showed a dramatic increase as influent COD concentration increased, which is due to a high solid loading rate into the system. Total suspended solids (TSS) in the effluent in low influent concentration were high which may due to biomass loss in the beginning of the experiment. It is believed that the sloughed biomass from the first run may become reattached. When the influent COD concentration increased to $4382 \mathrm{mg} / \mathrm{l}$, the performance of the reactor dramatically reduced. The total average of TSS, and turbidity of the effluent increased which may be due to the high cell production that do not like to integrate to form a floc or due to high death rates. The DO level decrease may be due to the increase of microorganisms' activity.

Table 3: $\quad$ Effluent qualities of SBFFBR system under HRT of 1.6 day.

\begin{tabular}{|c|c|c|c|c|}
\hline \multirow{2}{*}{$\begin{array}{l}\text { Influent waste } \\
\text { strength mg/l } \\
\text { COD }\end{array}$} & \multicolumn{4}{|c|}{ Effluent Characteristics } \\
\hline & $\begin{array}{l}\mathrm{TSS} \\
\mathrm{mg} / \mathrm{l}\end{array}$ & $\mathrm{DO} \mathrm{mg} / \mathrm{l}$ & $\mathrm{pH}$ & $\begin{array}{c}\text { Turbidity } \\
\text { (NTU) }\end{array}$ \\
\hline 610 & 10 & 5.9 & 6.7 & 1.6 \\
\hline 2041 & 2 & 4.55 & 7.1 & 1.93 \\
\hline 4382 & 186 & 1.32 & 7.4 & 32.7 \\
\hline
\end{tabular}

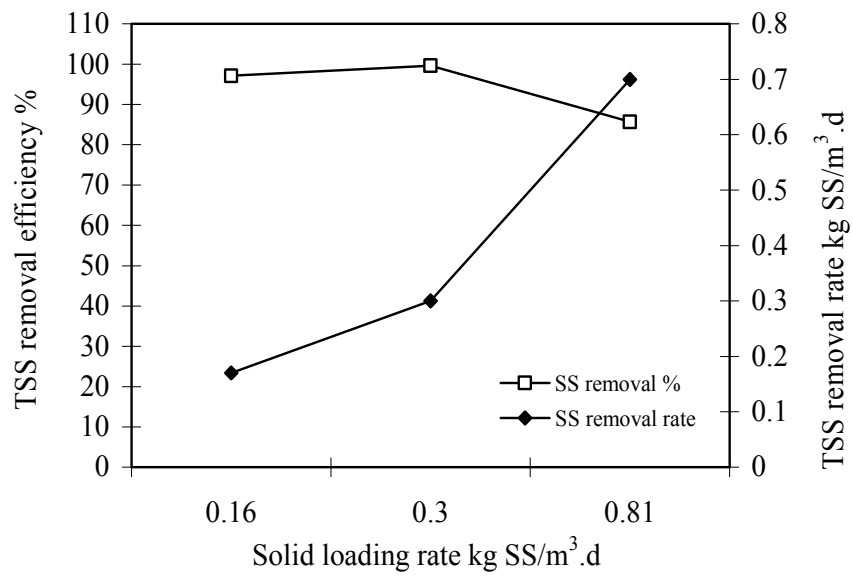

Figure 5: $\quad$ TSS removal efficiency and TSS removal rate.

The influence of the solid loading rate on the SBFFBR system performance is shown in fig. 5. The rate of TSS removal was strictly dependent on the solid loading rate (SLR), and rises fairly uniformly over the SLR studied. The percentage of TSS removal is fairly uniform at about $98 \%$ in the first and second points of solid loading rate. But, it drops off to $85 \%$ when the SLRs increased to $0.81 \mathrm{~kg} \mathrm{SS} / \mathrm{m}^{3} \mathrm{~d}$. 


\section{Conclusion}

A sequencing batch flexible fibre biofilm reactor has been developed for effective treatment of dairy processing wastewater. The COD removal efficiencies for a range of OLRs have been investigated and an inverse linear relationship between OLR and COD removal efficiency was observed. On the other hand a linear relationship between OLR and COD removal rate was observed. At an influent COD of about $4382 \mathrm{mg} / \mathrm{l}$ and an OLR $2.74 \mathrm{~kg}$ $\mathrm{COD} / \mathrm{m}^{3} . \mathrm{d}$, COD removal efficiencies of $89.7 \%$ were achieved at 1.6 day HRT. The overall removal efficiency was $94 \%$. Therefore, the SBFFBR system could be attractive for use in the treatment of milk industrial wastewater because of high carbon removal efficiency, good effluent quality, and low amount of sludge produced.

\section{References}

[1] Metcalf \& Eddy., Wastewater Engineering: Treatment and Reuse, (4th ed.): New York: McGraw-Hill, 2003.

[2] Sirianuntapilboon, S., Jeeyachok, N. \& Larplai, R., Sequencing batch reactor biofilm system for treatment of milky industry wastewater. Journal of Environmental Management, 76(2), pp. 177-183, 2005.

[3] Gavrilescu, M. \& Macoveanu M., Process engineering in biological aerobic wastewater treatment. Acta Biotechnology, 19(22), pp. 111 - 145, 1999.

[4] Xu, H., Review of methods of biological treatment of food processing wastewater. Proc. of $28^{\text {th }}$ Australian Chemical Engineering Conf. (Chemeca'2000 (CD-ROM), eds. Q.Yu, Perth, Australia, July 9-12, 2000.

[5] Abdulgader, M. E., A review of the performance of aerobic bioreactors for treatment of food processing wastewater. Proc of $1^{\text {st }}$ Conf on Environmental Management, Engineering, Planning and Economics, eds. Q. J. Yu, P. Williams \& A. A. L. Zinatizadeh, Greece, pp. 1131-1136, 2007.

[6] Yu, Q. J., Xu, H., Yao, D. \& Williams, P., Development of a two-stage flexible fibre biofilm reactor for treatment of food processing wastewater. Water Science and Technology, 47(11), pp. 189-194, 2003.

[7] Garrido, J. M., Omil, F., Arrojo, B., Mendez, R. \& Lema, J. M., Carbon and nitrogen removal from a wastewater of an industrial dairy laboratory with a coupled anaerobic filter-sequencing batch reactor system. Water Science and Technology, 43(3), pp. 249-256, 2001.

[8] Keller, J., Watts, S., Battye-Smith, W. \& Chong, R., Full-scale demonstration of biological nutrient removal in a single tank SBR process. Water Science and Technology, 43(3), pp. 355-362, 2001.

[9] Grady, P.L.J., Daigger, G.T. \& Lim, H.C., Biological wastewater treatment, $2^{\text {nd }}$ ed, Marcel Dekker: New York, 1999.

[10] Mohan, S. V., Rao, N. C., Prasad, K. K., Madhavi, B. T. V. \& Sharma, P. N., Treatment of complex chemical wastewater in a sequencing batch 
reactor (SBR) with an aerobic suspended growth configuration. Process Biochemistry, 40(5), pp. 1501-1508, 2005.

[11] Bandpi, A. M. \& Bazari, H., Biological treatment of dairy wastewater by sequencing batch reactor. Iranian Journal of Environmental Health Science and Engineering, 1, pp. 65-69, 2004.

[12] Casey, E., Glennon, B. \& Hamer, G., Oxygen mass transfer characteristics in a membrane-aerated biofilm reactor. Biotechnology and Bioengineering, 62(2), pp. 183-192, 1999.

[13] Najafpour, G. D., Zinatizadeh, A. A. L. \& Lee, L. K., Performance of a three-stage aerobic RBC reactor in food canning wastewater treatment. Biochemical Engineering Journal, 30(3), pp. 297-302, 2006.

[14] Andreottola, G., Foladori, P., Ragazzi, M. \& Villa, R., Treatment of winery wastewater in a sequencing batch biofilm reactor. Water Science \& Technology, 45(12), pp. 347-354, 2002.

[15] APHA, Standard methods for the examination of water and wastewater, Washington, DC: American public Health Association, 1995.

[16] Rodgers, M., Zhan, M. \& Burke, M. D., Nutrient removal in a sequencing batch biofilm reactor (SBBR) using a vertically moving biofilm system. Environmental Technology, 25(2), pp. 211-218, 2004. 